\title{
WORKPLACE HEALTH PROGRAMMES AS RISK MANAGEMENT TOOLS
}

Ágnes Szabó - Péter Juhász

Risks relating to the health of employees account for considerable damage worldwide. Corporate health programmes are a means to address this type of operational risk. There are a number of parallels between the process of introducing and maintaining such programmes and that of enterprise risk management programmes. While these well-being programmes are very popular in an international setting and especially at multinational companies, in Hungary, they are still in their infancy. Based on the interviews conducted with the 14 Hungarybased companies, which may be regarded as leaders in this field, there is ample room for development in the application of the programmes, especially in the measurement of outcomes.

JEL codes: G32, I18, J32, M12, M14, M54

Keywords: operational risk, corporate health programme, risk management, Fittest Workplace

\section{INTRODUCTION}

What makes a company healthy? Company health may be defined as competitiveness, i.e. efficient operation and growth in line with current possibilities, e.g. at the general rate of growth of the industry concerned. A healthy organisation may also be defined as one which offers its employees a healthy working environment, and has concern for the physical and mental health and well-being of its employees. In a third approach, an association may be healthy by offering its customers good and healthy products and services, and at community level, by exhibiting concern not only for its own business interests but also for the natural environment and external stakeholders during operation (Aidoo et al., 2015). This paper is focussed on the health of employees.

It is far from being a novel concern, having regard to the fact that occupational health has been on the WHO's agenda since the 1950 (Health Management, 2018). The WHO made clear that it is not simply work and the workplace that have an effect on the physical and mental health of employees. It also works the other way around: employee health also affects the company and its performance. Maintaining employee health is therefore critical in several respects: firstly, at the level 
of individuals and their families; for society, which often bears (part of) the costs of restoring health; and naturally, for company owners, whose main concern is profitability.

In the European Union, 600 million working days are lost due to work-related ill-health each year. The main causes are accidents, musculoskeletal disorders and stress at work. EU-OSHA (2018) estimates that work-related diseases account for about 200 ooo deaths across Europe yearly. Work-related health damage and injuries are costing the European Union EUR 476 billion every year. This means that at current prices, more than $3.2 \%$ of the total 2016 EU GDP (Eurostat, 2018), and more than four times Hungary's GDP (HCSO, 2018a) was lost due to these reasons.

Data from the Hungarian Central Statistical Office (KSH, 2018b) show an adverse trend in Hungary over recent years. Absence from work due to illness per employee increased by more than $25 \%$ from 2011 to 2016 , and the average length of paid sick leave also grew by almost 20\% (Table 1). The greater the staff headcount, the more working days are lost on average due to illness. Organisations having 5-49 employees reported an average of 3.8 days of sick pay or sick leave (4.6 days for blue-collar workers, 2.6 days for white-collar workers). The figure increases to 8.7 days at organisations of 50-249 employees (10.4 and 5.7 days, respectively), which is still much lower than the 11.2 days of absence (14 and 7.1 days, respectively) recorded at enterprises with a headcount of at least 250 (Vöö, 2018).

\section{Table 1}

Sick leave at enterprises with at least 50 employees

\begin{tabular}{lccccccc}
\hline & $\mathbf{1 9 9 2}^{\star}$ & $\mathbf{1 9 9 5}$ & $\mathbf{1 9 9 9}$ & $\mathbf{2 0 0 2}$ & $\mathbf{2 0 0 5}$ & $\mathbf{2 0 1 1}$ & $\mathbf{2 0 1 6}$ \\
\hline $\begin{array}{l}\text { Full-day absence from } \\
\text { work due to sickness }\end{array}$ & 16,9 & 16,5 & 16,2 & 14,0 & 13,1 & 8,1 & 10,3 \\
of which sick leave & 4,9 & 5,5 & 6,2 & 5,1 & 5,1 & 3,8 & 4,5 \\
\hline
\end{tabular}

Note: ${ }^{\star}$ Companies having at least 51 employees in 1992

Source: HCSO (2018b)

In 2017, the European Commission issued a communication for the modernisation of occupational safety and health legislation and policy (European Commission, 2017). According to the Communication, investment in occupational safety and health is profitable, as it improves business productivity and performance, and at macroeconomic level, contributes to national competitiveness. Employers have a positive return on investment in occupational safety and health.

Workplace Health Promotion (WHP) includes the promotion of healthy lifestyles, the maintenance and promotion of workers' health and working capacity 
as well as the improvement of working environments and work practices. Nowadays, companies - often to comply with the relevant legislative provisions - organise routine medical screening, which should also serve the aim of identifying and assessing health risks (Aidoo et al, 2015). Workplace health and wellness programmes are therefore a special tool of corporate risk management, directed mainly at operational risks associated with employees.

The applicable Hungarian regulation is based on Directive 89/391/EEC on the introduction of measures to encourage improvements in the safety and health of workers at work, which introduced the definition of risk. In this context, risk is asymmetrical, meaning the combined effects of the probability and severity of injury or health-related harm in an emergency. 'Risk assessment is practically a careful review of the possible harms and threats to employees at a given workplace and of the preventive measures that should be introduced' (Dabrónaki, 2017).

Workers may be exposed to several risk factors, including traffic, the weather, and also air, noise, light pollution or chemical contamination. Factors beyond the control of those whom they directly affect are not discussed in detail in this paper. Instead, the main focus is on risk factors employees have an influence on (diet, physical activity and stress) and on how these are addressed. However, it is important to take all factors into account at company level and that corporate health programmes consider changing every risk factor that emerges internally, i.e. factors modifiable by the organisation. Such factors are generally more numerous than risks factors modifiable by employees.

\section{MAIN RISK FACTORS}

The well-being of employees is influenced by numerous factors. While health research is mainly focussed on factors having adverse effects, factors exerting a positive effect on mental health (the only exception may be stress) are at the centre of the literature on human resources management, and management and leadership. As in risk management in general, for the purpose of assessing health risks, it is the most reasonable to categorise them according to (1) trigger, (2) form of expression (result) or (3) reason of exposure. Mixing these criteria results in overlapping categories, which not only distorts the results of the assessment but also make it extremely difficult to allocate risk management tasks and to define roles and responsibilities.

The survey of Willis Towers Watson (2016) of 1,669 employees in 34 countries revealed that stress is the most important risk factor for employees both globally and in Europe, followed by lack of physical activity (Table 2). It should be noted, however, that the phenomenon of presenteeism (suboptimum performance at 
work due to lack of full health) featured in the table is a risk factor mainly from the point of view of productivity rather than a trigger as the other listed factors. The results are therefore difficult to interpret due to the overlapping categories.

Table 2

Main health risks at the workplace

\begin{tabular}{cc}
\hline Global & Europe \\
\hline Stress $64 \%$ & Stress $74 \%$ \\
Lack of physical activity 53\% & Lack of physical activity $45 \%$ \\
Overweight/obesity $45 \%$ & Presenteeism $33 \%$ \\
Poor nutrition 31\% & Overweight/obesity $32 \%$ \\
Lack of sleep 30\% & Poor nutrition $31 \%$ \\
\hline
\end{tabular}

Source: Willis Towers Watson (2016)

Research conducted by Serxner et al. (2001) with 34,451 USA-based employees showed that those having problems in the areas of mental health, back pains, stress at work, lack of physical activity and overweight are $150 \%, 140 \%, 131 \%, 118 \%$ and $116 \%$ more often on sick pay, respectively, than the average. According to the surveys of Gallup Institute (Witters-Agrawal, 2015), engaged employees who also have high well-being scores are $30 \%$ more likely not to miss any workdays because of poor health in any given month compared with employees who have high engagement but otherwise exhibit low levels of well-being. In addition, employees with high levels of well-being miss $70 \%$ fewer workdays because of poor health over the course of a year.

The survey by the European Agency for Safety and Health at Work showed that the health of almost one quarter of the working population in the 27 EU Member States is at risk due to excessive stress at work (Szabó, 2018). Based on the 2010 European Survey of Enterprises on New and Emerging Risks (European Agency for Safety and Health at Work, 2010), while $79 \%$ of European managers are affected by stress at work, less than $30 \%$ of the enterprises address the problem.

Stress as a psychosocial risk factor is defined also in the Hungarian Act on Labour Safety from 2008. 'According to the definition psychosocial risk means the effects to which a worker can be exposed at work (conflicts, organization of work, work schedule, uncertainty of employment etc.), that have an influence in connection with his reactions to such effects, or in consequence of which stress, occupational accidents may occur, and psychosomatic symptoms (relating to or involving both the mind and body) may develop' (Dabrónaki, 2017). 
$13 \%$ of Hungarian employees continuously and an additional $30 \%$ often experience work-related stress (Szinapszis, 2013). According to the results of the 2013 Hungarian Work Stress Survey, fast pace of work is the most significant stressor. Stress at work is clearly reduced by clarity of roles, meaningfulness of work and a good social community at work.

According to an EU-level survey (Eurofound, 2010; Szabó, 2018) work-related stress accounts for 50 to $60 \%$ of working days lost. Based on a survey by the European Agency for Safety and Health at Work, unaddressed stress at work leading to reduced productivity costs the EU EUR 136 billion (1\% of the GDP) annually, and in particular HUF 440 billion in Hungary.

Another frequently-mentioned phenomenon is presenteeism, meaning not operating at maximum capability at work. In this case, employees perform their work in a state of mental or physical exhaustion or illness, and consequently their level of productivity is lower than when they feel well. They need more time for the same task, their capacity, motivation as well as the quantity and quality of the work they perform is reduced, and they interact less with their colleagues and clients.

Research by Eurofound (2012) shows that although managers have the lowest sickness absence rate, presenteeism is the most characteristic to them. The phenomenon is more prevalent also in the case of people with financial problems, workaholics, high-skilled white collar workers, older and childless workers, insomniacs and people with unhealthy lifestyle choices (Garrow, 2016). The probability of presenteeism is $28 \%, 66 \%$ and $50 \%$ higher in the case of smokers, employees with an unhealthy diet and who don't exercise very much, respectively, than in the case of those with better health behaviours (Aldana, 2018d).

What are the reasons behind presenteeism? It can be explained by personal reasons, e.g. the belief or the actual circumstance that nobody else can do our job. Loyalty (trying to avoid negative consequences for colleagues, clients and the company), fear of losing one's job and financial considerations (low sick pay or reduced premium) may also be mentioned here. Organisational factors and corporate culture (my manager works while sick, so I cannot be absent either; colleagues are gossiping about absentees) may also contribute to presenteeism (Baker-McClearn et al., 2010).

The main reasons (risk triggers) behind presenteeism as a risk for productivity are allergies, depression, burnout, stress or other mental diseases, tiredness, diabetes, musculoskeletal complaints, colds, headaches or any infectious disease. In addition, many of the triggers may cause additional damage, e.g. the sick employee may infect others or the symptoms may divert their attention and reduce their motivation for work, too. Lowered employee morale may further deteriorate performance at the level of the company as a whole. 
Some research suggests that lost productivity may be 7.5 times greater with presenteeism than absenteeism, and its costs may be 3 times higher than the amount spent on sickness benefits (Garrow, 2016). Estimates from various countries based on different methodologies set the costs of presenteeism for the national economy at a meagre 0.2 to more than $3 \%$ of the GDP (DeVol-Bedroussian, 2007). In the United Kingdom, the cost of absences per capita is EUR 486 while that of presenteeism is EUR 895.

In its survey of 2,00o employees in 17 countries, Virgin Pulse (2017) found that the sampled employees take four sick days off per year on average but they reported 57.5 not fully productive working days per year on average. However, the various data on presenteeism should be interpreted with circumspection. There is no generally accepted and established measurement methodology; moreover, the applied self-assessment tests are often based on the Likert scale, which measures agreement with a few simple statements. In addition, the phenomenon may show significant differences by culture, country, over time and even by industry (Figure 1).

\section{Figure 1}

\section{Impact of presenteeism on industry production (\%, Australia)}

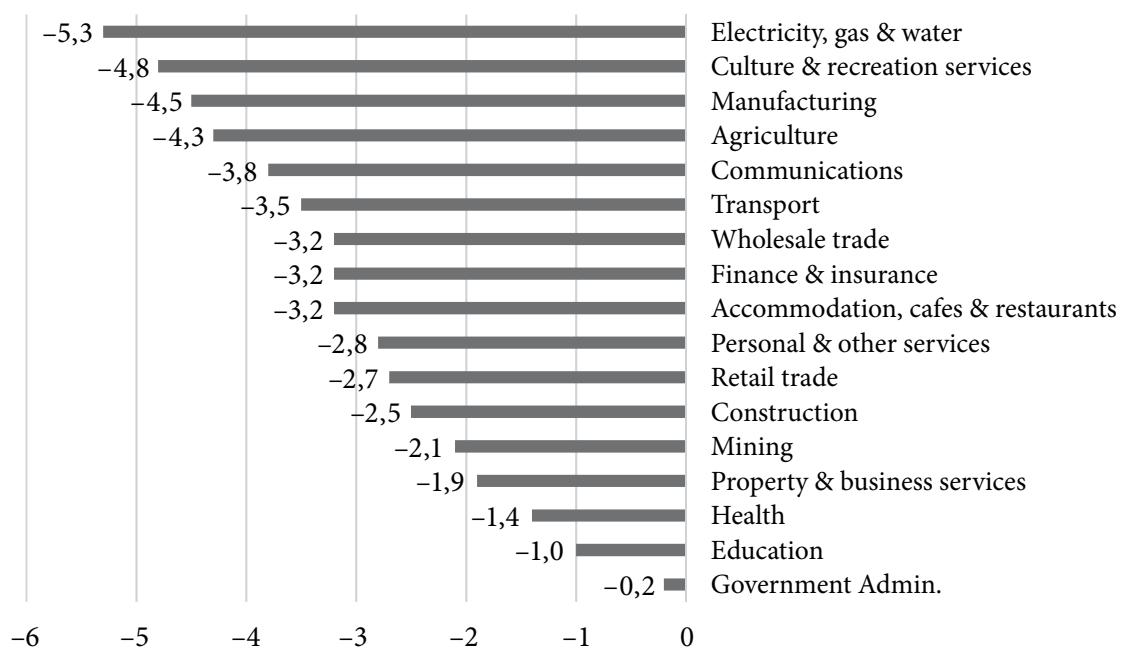

Source: KPMG Econtech (2011), cited in Garrow (2016)

Physical inactivity is also a rich source of problems. Lechner (2009) provided empirical evidence on the impact of physical activity on earnings based on data from a German panel study over the period 1984-2006, i.e. that leisure sports participation resulted in a monthly earnings gain of EUR 100 on average for German em- 
ployees. Regular physical activity improves the concentration and mood of people both temporarily and in the long term. It also has a protective function whereby it enlarges and strengthens the hippocampus and the prefrontal cortex, which provides protection against incurable illnesses such as Alzheimer's or dementia. Despite all these beneficial effects, according to the 2010 Eurobarometer (2010) survey, only $5 \%$ of the Hungarian population did sports five times a week, but also the proportion of those engaged in physical activity less often was only $18 \%$. More recent data from the 2014 Eurobarometer (2014) survey show an increase to $15 \%$ in the proportion of those doing sports five times a week and to $23 \%$ in the proportion of those engaged in physical activity less often but regularly, which, however, is still below the EU average of $33 \%$.

The Randstad Workmonitor (2014) survey reveals that 15\% of Hungarians have the opportunity to work out during office hours, but only $16 \%$ are offered gym facilities in-house or a discount to a sports facility outside working hours by the employer. The corresponding figure is $26 \%$ in Australia, $33 \%$ in Poland, $40 \%$ in the USA and $67 \%$ in Sweden.

Overweight and an unhealthy diet are also frequently mentioned health risks. However, the former is a result of other factors rather than a risk factor in its own right. People with a BMI of 25 to 30 are defined as overweight and those with a BMI over 30 fall within the obese range. In 2014, there were almost 2 billion overweight and 600 million obese people around the world. The proportion of overweight people doubled over the last twenty years. 2.8 million people die of health consequences of overweight and obesity every year, which are therefore the fifth leading cause of death.

Based on the Obesity Update 2017 study of OECD (2017), among OECD countries, only the United States, Mexico and New Zealand has higher obesity rates than Hungary. According to the report, $30 \%$ of the Hungarian population aged 15 years and over is obese (OECD, 2017). 16\% of Hungarian children below 15 years of age are overweight. When only the adult population is considered, based on the health check prepared by the Hungarian National Institute of Pharmacy and Nutrition (OGYÉI), two in three adults are overweight or obese (Polgár, 2018).

According to WHO data, overweight and obesity account for $44 \%$ of the diabetes cases, $23 \%$ of the ischemic heart disease patients, and around $7-41 \%$ of certain cancers. Obesity is virtually a necessary addition to high blood pressure, high cholesterol and diabetes. The treatment of health problems associated with obesity costs the Hungarian state and population a total of HUF 229 billion every year (Polgár, 2018).

The Hungarian situation as regards healthy diet is illustrated well by HCSO data, which reveal that only $40 \%$ of the population over 16 years of age eat fruit on a 
daily basis and fresh vegetables are consumed daily by only $30 \%$. Fruit and vegetable consumption is closely associated with financial standing as well; women and those with higher qualifications and income eat them more frequently (Pénzcentrum, 2018).

Lack of sleep is also a serious risk. The brain needs to sleep in order to dispose of the by-products of neural activity. When it does not get enough sleep, the remaining toxic proteins hinder it and slow down the processing of new information and problem solving, and stifle creativity. Lack of sleep is also a health threat which may be associated with serious medical problems such as heart attacks, strokes, type 2 diabetes and obesity.

Research (The Sleep Council, 2013) shows that only 8\% of British employees say that they feel rested when they wake up, i.e. $92 \%$ are already tired when they start work. According to findings of the statistics company Rand Europe (Rand Europe, 2016), the physical and mental illnesses of British employees caused by insufficient sleep amounted to a loss in GDP of almost GBP 40 billion in 2016. Based on a study from the University of Michigan (Brooks, 2015), short naps or extended breaks offered to employees during working hours improve their productivity on the whole and boost their tolerance for frustration. This is applicable especially to employees who are not able to sleep through the night for some reason.

The association between specific health risks and productivity has been studied in several respects. In the human performance model of O'Donnell (2000), the performance of employees improves when they are physically and emotionally well, and have a desire to work. This reduces absenteeism and presenteeism, which in turn enhances performance. Aldana (2001) found that, of all health risks, growing excessive body weight and stress are the ones that could be certainly associated with increased health care costs and illness-related absenteeism.

By contrast, Boles et al. (2004) studied 11 health risks, namely poor diet, BMI, high cholesterol, physical inactivity, stress, overdue preventive visits, lack of emotional fulfilment, high blood pressure, tobacco use, diabetes or high blood glucose, and alcohol use (the risk areas typically analysed in relevant research). Their results show that more productivity loss was experienced by respondents having more risks. Potential productivity loss was highest in the case of diabetes (absenteeism) and stress (presenteeism). The value of productivity loss due to these risks was more than USD 67 per person in a 1-week period. Pelletier et al. (2004) concluded that eliminating one health risk affecting an individual reduces absenteeism by $2 \%$ and improves their presenteeism by $9 \%$. Burton et al. (2006) also proved that an increase in health risks is associated with a same-direction change in presenteeism. 
According to Vaughan-Jones and Barham (2009), employees considered to have a medium to high risk of disease as a result of their eating and exercise habits can be 6-12\% less productive than those with low health risks. The findings of Lenneman et al. (2011) corroborate that reducing employees' health risks leads to improved health status and less productivity impairment. Even reducing the high-risk status of an individual to low-risk in respect of physical inactivity, stress, depression or body weight decreased productivity loss.

Goetzel et al. (2012) showed that more than $20 \%$ of corporate health care costs are attributable to modifiable health risks, namely depression, high blood glucose, high blood pressure, obesity, tobacco use, physical inactivity and high stress. Based on Merrill et al. (2013), higher job performance was 1.2 times more likely among those who exercised for 30 or more minutes on at least three days a week and who ate five or more servings of fruit and vegetables on four previous days than among those who did not.

Kirkham et al. (2015) carried out a risk assessment for 17,089 employees across a 4-year study period (2007-2010). According to their findings, emotional health, inadequate exercise, tobacco use and body mass index (BMI) at age 35 may be consistently associated with both absenteeism and presenteeism. Hypertension, blood sugar, inadequate exercise and alcohol could be associated with absenteeism and suboptimum work among older workers. Productivity loss is most strongly related to emotional health and obesity.

The correlational analyses of Hayman (2016) indicate that exercise, tobacco use, body mass index and nutrition are significantly related to workplace productivity. While exercise and nutrition had a significant positive correlation with workplace productivity, tobacco use and increasing BMI were negatively correlated with workplace productivity. According to the regression analysis results in the study, these variables explain $21 \%$ of the variance in productivity.

Based on WHAA (2016), high risk employees (5+ risks) are not productive $32.7 \%$ of the time spent at the workplace and are absent 5.1 hours/month on average compared to low risk employees (o-2 risks) who are not productive $14.5 \%$ of the time and absent only 2.4 hours/month. The productivity difference between healthy and unhealthy employees is therefore $18.2 \%$, corresponding to 45 working days per annum. Absenteeism and to some extent presenteeism (see Tables 3 and 4) are attributable to various health and lifestyle factors. Higher absence rates are recorded for higher-risk employees, who are also less productive. 
Table 3

Contribution of risk factors to absenteeism and presenteeism

\begin{tabular}{lccc}
\hline Risk factor & Absenteeism & Presenteeism & Total \\
\hline Type 2 diabetes & $4.94 \%$ & $18.26 \%$ & $23.20 \%$ \\
Depression & $2.61 \%$ & $14.51 \%$ & $17.12 \%$ \\
Alcohol abuse & $5.00 \%$ & $4.78 \%$ & $9.78 \%$ \\
Overweight/obesity & $1.40 \%$ & $8.30 \%$ & $9.70 \%$ \\
High cholesterol & $3.14 \%$ & $4.91 \%$ & $8.05 \%$ \\
Tobacco use & $2.84 \%$ & $4.78 \%$ & $7.62 \%$ \\
Chronic stress & $3.08 \%$ & $4.45 \%$ & $7.53 \%$ \\
Asthma & $4.80 \%$ & $1.20 \%$ & $6.00 \%$ \\
Migraine & $3.96 \%$ & $1.99 \%$ & $5.95 \%$ \\
Physical inactivity & $0.28 \%$ & $4.59 \%$ & $4.87 \%$ \\
\hline
\end{tabular}

Source: WHAA (2016)

Table 4

Association between employee risk levels and absence and productivity

\begin{tabular}{lcc}
\hline Risks & $\begin{array}{c}\text { Mean annual } \\
\text { absent days }\end{array}$ & $\begin{array}{c}\text { Mean annual } \\
\text { unproductive days }\end{array}$ \\
\hline Low (0-2 risks) & 1.6 & 5.1 \\
Medium (3-4 risks) & 2.4 & 12.9 \\
High (5+ risks) & 3.6 & 28.9 \\
\hline
\end{tabular}

Source: WHAA (2016)

Table 5 summarises research results on risk factors. Physical inactivity, stress and obesity (high BMI, poor nutrition) seem to have the greatest negative impact on productivity. Therefore, companies should focus primarily on these risk areas in their health programmes. 
Table 5

Main risk factors reducing productivity

\begin{tabular}{|c|c|c|c|c|c|c|c|c|}
\hline & 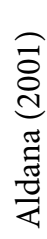 & 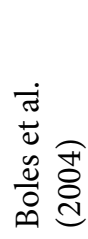 & 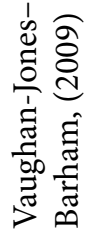 & 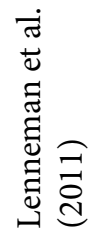 & 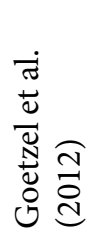 & 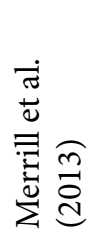 & 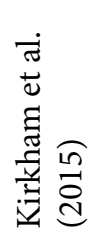 & 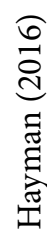 \\
\hline $\begin{array}{l}\text { Physical } \\
\text { inactivity }\end{array}$ & & & $\mathrm{x}$ & $\mathrm{x}$ & $\mathrm{x}$ & $\mathrm{x}$ & $\mathrm{x}$ & $\mathrm{X}$ \\
\hline Stress & $\mathrm{x}$ & $\mathrm{x}$ & & $\mathrm{x}$ & $\mathrm{x}$ & & $\mathrm{x}$ & \\
\hline Obesity/BMI & $\mathrm{x}$ & & & $\mathrm{x}$ & $\mathrm{x}$ & & $\mathrm{x}$ & $\mathrm{x}$ \\
\hline Poor nutrition & & & $\mathrm{x}$ & & & $\mathrm{x}$ & & $\mathrm{x}$ \\
\hline Tobacco use & & & & & $\mathrm{x}$ & & $\mathrm{x}$ & $\mathrm{x}$ \\
\hline Blood glucose & & $\mathrm{x}$ & & & $\mathrm{x}$ & & $\mathrm{x}$ & \\
\hline Blood pressure & & & & & $\mathrm{x}$ & & $\mathrm{x}$ & \\
\hline Depression & & & & $\mathrm{x}$ & $\mathrm{x}$ & & & \\
\hline Alcohol & & & & & & & $\mathrm{x}$ & \\
\hline
\end{tabular}

Source: authors' elaboration

\section{THE STRUCTURE OF SUCCESSFUL WORKPLACE HEALTH PROGRAMMES}

As with all risk management systems, the first step should be the exploration of the current situation. The health status of employees and risk factors can be appraised using a health risk assessment (HRA) questionnaire. The HRA (Mills, 2005) collects data from individuals and in addition to identifying risks, it can also provide personalised feedback. Since part of the risks are caused by employees by their own undesirable behaviours (moving around carelessly, smoking, alcohol consumption and drug use) or neglect of desirable behaviours (exercise, healthy diet), the sheer existence of such an assessment and the evaluation of the results by an expert serve as risk assessment tools, as they reduce the probability of such risks. Trainings on safety at work aim to manipulate in the same way, however, generally no data are collected within the framework of such trainings.

A typical HRA questionnaire collects information on demographics (gender, age), lifestyle (tobacco use, physical activity, alcohol consumption, diet, medication, sleep habits, stress), and individual and family medical history (hereditary 
predispositions, vaccines). Sometimes, physiological data (height, weight, blood pressure, cholesterol levels) are also collected. The HRA method is often criticised on the grounds that the questionnaires are too long (low rate of full completion), they are self-rated (mistakes, distortions), self-completed (misunderstandings), data collection has no practical use (the data are not analysed, there is no followup or feedback), the protection of personal data is not always ensured (unauthorised access, retaliation by the employer for honest responses on problems) and they do not necessarily bring about change (there is no change of behaviour on either employer or employee side).

It is critical for the success of a corporate health programme to gain commitment from the major stakeholders and key opinion leaders (WHO, 2010). There are obvious parallels with experience from enterprise risk management (ERP) programmes, in the case of which integration into corporate culture is indispensable (Oliveira et al., 2018). In addition, support from the senior management and a steering committee is also needed for both types of programmes. This committee is responsible for the establishment of an enabling environment within the organisation, transmission of the necessary information and for the motivation and training of potential participants. As with ERM systems, the status quo should be appraised first (medical examinations, tests, questionnaires, statistics).

An objective should be set. Focus areas should be defined, taking into account not only the risks to be addressed but also the expected costs and outcomes of the programme. The 3 to 5 -year strategic plan should be broken down to annual programmes. Just as for the operation of ERM programmes, targets, tools, processes, responsibilities and the available time and budget should also be specified.

Participants generally need continuous support during implementation and regular feedback is also required. For success, it is not enough to simply follow up on change; appreciation should be expressed regularly to participants for their efforts. Reflecting on efficiency and changing circumstances, the programme should be reviewed periodically based on the lessons learned (WHO, 2010), as is customary in the case of ERM systems (International Organization for Standardization, 2018).

\section{THE EFFECTS OF HEALTH PROGRAMMES}

Compliance with health protection directives is the most difficult for SMEs. 93\% of EU-based enterprises are micro-sized, and regular risk assessment is carried out at only $69 \%$ of them, compared with 96\% at larger enterprises (Dabrónaki, 2017). According to the data of Xerox (2016), in 2008, 34\% of multinational companies launched a health promotion programme globally, which continued to rise to $56 \%$ in 2014 and to $69 \%$ in 2016 . Corporate health promotion costs were in the 
range of USD 150 to 1,200 per employer per year at international level in 2018. Aldana (2018a) argues that these wellness programmes have the potential to add value for the company in four ways:

1) by improving the health behaviours of employees,

2) by improving productivity (less absenteeism and presenteeism),

3) by helping employee retention,

4) by improving employee morale and workplace atmosphere (Aldana, 2018b, 2018c).

At the same time, such programmes need time. International research shows (Table 6) that a company health and well-being programme encouraging colleagues to do sports together may change the workplace atmosphere, and improve team cohesiveness and engagement within a few months already. However, measurable improvements in performance and productivity only appear after 1-2 years, just like positive changes regarding company image and quantifiable increases in employee health knowledge and satisfaction. Reduced fluctuation is also perceptible after this period. 3-5 years are required for noticeable reductions in workplace injuries and accidents, sickness, absenteeism and presenteeism to occur and to achieve a return on investment in employee training and development (Tasmania, 2012).

\section{Table 6}

The effects of workplace health and well-being programmes

\begin{tabular}{lll}
\hline Within a few months & Within 1-2 years & Within 3-5 years \\
\hline $\begin{array}{l}\text { Higher employee } \\
\text { engagement }\end{array}$ & $\begin{array}{l}\text { Higher productivity } \\
\text { and performance }\end{array}$ & Less workplace injuries \\
$\begin{array}{l}\text { Better employee morale } \\
\text { Better workforce } \\
\text { retention and attraction } \\
\text { cohesiveness, } \\
\text { sense of community }\end{array}$ & $\begin{array}{l}\text { Lower illness } \\
\text { and absence rates }\end{array}$ \\
& $\begin{array}{l}\text { Better individual health } \\
\text { knowledge }\end{array}$ & $\begin{array}{l}\text { Better ROIs on training } \\
\text { and development }\end{array}$ \\
& Higher job satisfaction & \\
\hline
\end{tabular}

Source: Tasmania (2012, p. 15)

Apart from overviews of overall empirical evidence, the literature also provides explicit measurement approaches. Three of these approaches are widely applied. The focus may be on (1) measurable benefits for the employer in monetary terms 
(return on investment, ROI), (2) changes at individual and group-level, which are often subjective and hardly measurable (value on investment, VOI), or (3) potential social benefits (social return on investment, SROI).

While companies adopting a simple ROI approach only take into account the financial return on the capital invested in health promotion, companies using a VOI approach assess changes in factors that add value (promote health). Measurement is more problematic under the VOI approach, as in addition to easily measurable indicators such as accidents, days of absence and health care costs, employee morale, engagement and well-being, among others, should also be monitored. In a VOI approach, personal data protection should also receive more attention, considering that anonymization may not be sufficient to prevent the identification of individuals within smaller organisational units.

SROI, which has developed from health cost-benefit analyses, considers effects for the whole of society, but is limited almost exclusively to measurements in monetary terms. As the scope of beneficiaries is much wider under this approach, higher returns are measured than with ROI. However, the measurement of certain quantitative variables in monetary terms (e.g. human lives, prevention and treatment of diseases, increment in fertility rates) may entail serious ethical issues. Table 7 shows the potential savings for companies for every dollar invested in workplace health and well-being programmes based on the results of international research and meta-analyses, using a ROI approach.

Table 7

Estimated ROIs (per 1 USD invested)

\begin{tabular}{lccc}
\hline Source & $\begin{array}{c}\text { Health care } \\
\text { costs }\end{array}$ & $\begin{array}{c}\text { Absence-related } \\
\text { costs }\end{array}$ & $\begin{array}{c}\text { Total } \\
\text { savings }\end{array}$ \\
\hline Aldana (2001) & 3.48 & 5.82 & 4.30 \\
Goetzel et al. (2008) & & & $\begin{array}{c}1.40-4.70 \\
\text { (in 3 years) }\end{array}$ \\
Baicker et al. (2010) & 3.27 & 2.73 & \\
(in 2-3 years) & (in 2-3 years) & \\
Hongen et al. (2011) & $1.40-4.60$ & 2.70 & 3.92 \\
Henke et al. (2011) & & & $\begin{array}{c}\text { (between 2002 } \\
\text { and 2008) }\end{array}$ \\
Baxter et al. (2014) & & & 1.38 \\
$\begin{array}{l}\text { U.S. Chamber } \\
\text { of Commerce }\end{array}$ & & $\begin{array}{c}1.50-3.00 \\
\text { (in 2-9 years) }\end{array}$ \\
\hline
\end{tabular}

Source: authors' elaboration 
There is limited research on the effects of workplace health promotion initiatives in Hungary as these programmes have become more widespread only in recent years. A survey by MGYOSZ/BUSINESSHUNGARY (2010) of 709 regional companies shows that ergonomics developments predominate in the area of occupational health and safety (32\%), while more than $40 \%$ of the firms have no health promotion programme in place at all. The study of Szinapszis (2013) reveals that only $17 \%$ of the 400 interviewed Hungarian employees participated in a regular mandatory workplace health promotion programme.

\section{HUNGARIAN EXPERIENCES}

This empirical study is based on interviews carried out with award winners at the award ceremonies of the previous five Fittest Workplace Surveys (Legfittebb Munkahely felmérés), in-depth interviews with four first prize winners and a workshop held in March 2015. On these occasions, the success factors and effects of programmes implemented in Hungary were reviewed - in addition to other topics - with the interested survey participants and award winners. All award winners were asked at the ceremonies about the key to the success of their programmes and the effects they observed (see Table 8).

In the online Fittest Workplace Survey, forms of corporate health promotion and satisfaction therewith are surveyed in addition to employee habits, and the winners are selected based on an analysis of these thematic areas. The Survey and awards is not only a recognition for Hungarian companies for their active role in promoting employee health and physical activity; it also encourage the implementation of health and well-being programmes and provides an opportunity for the transfer of best practices between the companies. Typical survey participants are companies showing above-average commitment to the health and physical activity of their employees. Award winners go well beyond the average Hungarian employer in their efforts, therefore, the conditions they describe are much better than those prevailing at a typical workplace in Hungary. 
Table 8

Interviewees (award winners of the Fittest Workplace Survey)

\begin{tabular}{|c|c|c|c|c|}
\hline & $\begin{array}{l}\text { Small-sized } \\
\text { enterprise }\end{array}$ & $\begin{array}{l}\text { Medium-sized } \\
\text { enterprise }\end{array}$ & $\begin{array}{c}\text { Large } \\
\text { enterprise }\end{array}$ & $\begin{array}{c}\text { Public } \\
\text { administration }\end{array}$ \\
\hline 2013 & Hansgrohe Kft. & GE-Healthcare & HPE & - \\
\hline 2014 & SZ+C Stúdió Kft. & $\mathrm{HBO}$ & Unilever & $\begin{array}{l}\text { Kancellária SE } \\
\text { Sports Club }\end{array}$ \\
\hline 2015 & - & $\mathrm{HBO}$ & Unilever & $\begin{array}{l}\text { Sports Club } \\
\text { of the Ministry } \\
\text { for National } \\
\text { Economy }\end{array}$ \\
\hline 2016 & $\begin{array}{l}\text { British American } \\
\text { Tobacco Hungary }\end{array}$ & $\mathrm{HBO}$ & Diageo & $\begin{array}{l}\text { Kancellária SE } \\
\text { Sports Club }\end{array}$ \\
\hline 2017 & $\begin{array}{l}\text { Evopro } \\
\text { Group }\end{array}$ & Tigra Kft. & $\begin{array}{l}\text { Contitech } \\
\text { Rubber Industrial }\end{array}$ & $\begin{array}{c}\text { National } \\
\text { Election Office }\end{array}$ \\
\hline
\end{tabular}

Source: authors' elaboration

The interviews with Fittest Workplace award winners indicate that corporate health promotion is in its infancy in Hungary. More complex programmes approximating those seen at international level are found only at three companies (Unilever, HPE, HBO, of which Unilever's is superior). There is a single company that pays due attention to the preliminary assessment of risks and the measurement of outcomes (Unilever). Award winners reported that their own reason for participating in the competition was to

5) get feedback and reinforcement that they are on the right path;

6) (spark dialogue within the company about the further development of, and new ideas about, health promotion;

7) have an insight into the practices of others and to learn.

In the following paragraphs, first the success factors of health programmes are examined and then their effects, added value and the applied measurement methods are summarised.

In the examination of success factors, theory and practice met, as almost all of the factors mentioned in the theoretical part of this paper re-occur. Senior managers should be committed to the health promotion programme and it should have strategic importance. If commitment by the senior management is provided, the necessary financial and human resources will not be a problem. Com- 
pany leaders may play an important role also in changing corporate culture. The importance of the health promotion programme should preferably be an integral part of company mission, vision and policy. According to the respondents: 'It all depends on the senior management. If they fall in love with it, everything will be fine.' 'It took a few years at our company too, until the senior management took it seriously.'

Realistic objectives are needed and a clear idea on the part of participants of what they want to achieve both individually and at company level. It is important to know the status quo and to create plans (time, money, people). It is very important to have a common goal.' 'Where am I now, where do I want to get, what is my aim you need to know these both in the short and long term, and also how and by what means you want to achieve them.'

A successful programme should be a long-term initiative. 'You shouldn't give up on the programme; it will not be established overnight. It takes years.'

Apart from these, the definition of needs and employee involvement are probably the most important: 'Employees should be involved right from the beginning and considered until the very end. They should be able to provide feedback.' 'Bottomup initiatives should be paid attention.' 'We are trying to cover the full diversity of needs.'

In addition to defining needs, a good programme should also include a health check (the mental and physical condition, nutritional and exercise habits and rates of absence of employees) and assessment of the results at individual level, to prepare a personal development plan (recommendation) in accordance with personal health risks and needs. These individual health checks may provide a basis for corporate programmes as well. (This was implemented in a professional manner only at one company).

Responsibility should be allocated at all levels to a group (or often a single person) in charge of all aspects of the workplace health promotion programme and its operation. Health promotion meetings should be held with the participation of as many organisational departments as possible. 'You need a local team everywhere.' 'You need an icon who will be the heart and soul of the whole thing.' 'There should be a driving force, someone committed, enthusiastic, resourceful and willing to do it properly.'

Events, presentations and programmes should be promoted through different channels to the participants. Employees should be motivated and encouraged to take part in as many events and programmes as possible. Appropriate channels of communication should be used which not only promote benefits and incentives, but enable employees to provide feedback and express their (dis)satisfaction. Various marketing tools may be used, but scientific facts and evidence may be just 
as effective. Both formal and informal channels should be put to use. 'They can come to me any time, but may also provide feedback anonymously.'

Although mentioned at the end of the list, evaluating and measuring the effects is probably the most important step. 'Measurability is a key to convincing the top management. This is how they will take it seriously. They want numbers.' Continuous evaluation, validation and improvement of the programme is made possible by measurements. While all companies consider it important in theory, only one award winner has a sophisticated measurement system in place and is able to provide precise figures.

At this company, mean absence per employee per year was reduced to 3.9 days, compared with a mean 8 days at country level. Using the ROI approach, the return on every Hungarian forint invested in the programme was HUF 3.73 The company in question also measures presenteeism and satisfaction. Precise figures or any information on the ROI of the programmes were not available anywhere else. 'It is difficult to follow it up by measurements.' 'We weren't sufficiently conscious in this respect, although it would be important to measure everything.' Interviewees often used the word 'feel', which suggests that they are aware of their shortcomings. They gave lengthy answers to the question 'What are the effects of the health promotion programme, how does it add value?', but based solely on subjective impressions.

A decrease in the number of sick days was referred to repeatedly. The observation in the international literature that physical activity and a healthy lifestyle reduce absenteeism is reinforced by practical experience in Hungary. 'The number of sick days is much lower in the case employees having a healthy lifestyle.' 'Health and a balanced lifestyle are instrumental to reducing sick leaves to the minimum.' 'We do not perform measurements, but see that our employees are more satisfied, are in better physical health and are absent less often due to illness.' 'The only thing we measure are days of absence, which decreased, indeed.'

Indirect reference was made to the VOI approach, but the term 'value on investment' or even the phrase 'add value' was not used by any of the interviewees. They have experienced in practice that health promotion programmes improve the health knowledge of employees, which in turn reduces their health risks relating to e.g. smoking, exercise or mental factors. 'Our company saw an increase in employees doing sports and a reduction in smokers., and as to mental factors, positive thinking has become more prominent.' 'We have achieved changes in lifestyle. I am very proud of that.'

The award-winning Hungarian company which had implemented a sophisticated measurement system had evidence to substantiate the finding that health programmes may increase and improve productivity and business performance. 
'We can show that there is an association between mental health and financial performance.' Although the other companies could not provide evidence in absolute terms, they feel (or, in the absence of measurements, suppose) that healthy employees are more efficient, productive and creative. 'Physical well-being affects mental performance, which is perceptible in employees' everyday work and work performance.' 'It certainly has a positive impact on company growth when employees are in good health.' 'Physically and mentally healthy employees are dedicated, cooperative and creative in their everyday work. Giving a boost to corporate sports life is not only beneficial to colleagues; it pays off to the company many times over. 'Colleagues are more motivated, rested and productive.'

Several interviewees mentioned morale, mood and relationships at the workplace. There were noticeable improvements in attitude to work, teamwork and cooperation have become smoother, and a genuine sense of community emerged. These improvements also had an impact on performance. The above statements are 'feelings' or impressions expressed by an HR manager or an employee responsible for sports, and may therefore be biased. It was mentioned repeatedly that such 'soft' factors are difficult to measure or evaluate (there is no established methodology in the international literature either). 'Relationships at the workplace have become stronger, leading to improvements in morale and performance." 'You can feel it in the general mood as well.' 'Sense of community is the primary objective and one of the main motives and benefits.' '...everyone participates enthusiastically in the in-house championship, it is a real team building force.' 'But these are difficult to measure.'

In the current situation, employee retention and the reduction of fluctuation are indeed a significant result of these programmes, just like satisfaction, creativity, and on employees' side, better looks. The Happy-or-Not application is a useful tool to measure satisfaction. 'Our colleagues are more loyal, creative and also more attractive.' 'They were more motivated to come to work, more satisfied and smiled more often.' 'Colleagues can express their degree of satisfaction with a very sad to a very happy emoji. It is a very popular application.' Based on data from the Fittest Workplace Survey questionnaire, motivators to sport in Hungary correspond with those featured in the literature, i.e. health, lower stress levels, relaxation and looks. It should be highlighted as a distinctive feature of the Fittest Workplace Survey, that better body image, good looks and stress relief received greater emphasis than measured at the level of society as a whole on average.

There are three factors identified in the international literature that were not mentioned at all among positive effects in the interviews with the Hungarian stakeholders, namely improvements in levels of energy, safety and general well-being. Notwithstanding, it is welcome that all the other benefits were perceived and identified by the interviewees. 
Of risk factors, physical inactivity, mental health/stress and tobacco use were touched upon in the interviews. The first two were mentioned the most often, which is in line with findings in the international literature. Although felt also by the Hungarian interviewees, except for one company, they could not provide measurement results in evidence.

\section{SUMMARY}

Employees' medical problems and mental and physical well-being have a direct impact on their productivity, efficiency and thereby on the business performance of their employers. It is therefore also in the interest of employers to help their employees in staying healthy and eliminating medical problems. Corporate health promotion programmes may be used as a tool for this purpose, which are able to address a specific category of operational risks.

Previous research has shown a strong correlation between certain risk factors and efficiency at work, which is recognised by a growing number of companies worldwide. Multinational companies are pioneers in the introduction of workplace health programmes. The most important risks in addition to physical inactivity, stress, overweight/obesity, poor nutrition, tobacco use, blood glucose and high blood pressure are depression and alcohol consumption.

The steps and principles of introducing and operating an enterprise risk management programme apply also to health programmes. At the same time, the protection of personal data and ethical problems such as prioritising different health problems and employee needs may pose a particular challenge. Employers may end up excluding the most vulnerable employees from the target population if they take only financial considerations into account.

As to the efficiency of the programmes, the assessment of their success may be based on at least three different approaches (ROI, VOI, SROI). Although there is no well-established and widely accepted standard methodology at present, simplified estimation tends to indicate that the different corporate health programmes are an efficient means of addressing employees' health risks also in financial terms.

The interviews conducted with representatives of the 14 Hungary-based companies which are leaders in the introduction of health programmes suggest that the majority of benefits described in the international literature have been experienced by participants and companies also in a Hungarian context. Still, the measurements of outcomes in absolute terms and the analysis of financial returns is still in its infancy. 


\section{REFERENCES}

Aidoo, H. - Essuman, A. - Aidoo, P. - Yawson, A. O. - Yawson, A. E. (2015): Health of the corporate worker: health risk assessment among staff of a corporate organization in Ghana. Journal of Occupational Medicine and Toxicology, 10:30. DOI: 10.1186/s12995-015-0072-7.

Aldana, S. G. (2001): Financial impact of health promotion programs: a comprehensive review of the literature. American Journal of Health Promotion, 15(5), p. 296-320. DOI:10.4278/0890-117115.5.296.

Aldana, S. G. (2018a): How much does an employee wellness program cost? https://www.wellsteps. com/blog/2018/o1/o7/employee-wellness-program-cost/ (downloaded on 08.02.2018).

Aldana, S. G. (2018b): 5 Workplace Wellness Statistics Every Employer Should Know, https://www. wellsteps.com/blog/2018/o1/o6/workplace-wellness-statistics-wellness-stats/ (downloaded on 08.02.2018).

Aldana, S. G. (2018c): 7 Reasons Workplace Health Promotion Programs Work, https://www. wellsteps.com/blog/2018/o1/12/workplace-health-promotion-programs/ (downloaded on 08.02.2018).

AldanA, S. G. (2018d): https://www.wellsteps.com/blog/2018/o7/o4/reasons-to-have-a-wellnessprogram-benefits-of-wellness/ (downloaded on 08.02.2018).

BAicker, K. - CutLeR, D. - Song, Z. (2010): Workplace wellness programs can generate savings. Health Affairs, 29(2), p. 304-311. DOI: 10.1377/hlthaff.2009.0626.

Baker-Mcclearn, D. - Greasley, K. - Dale, J. - Griffith, F. (2010): Absence management and presenteeism: the pressures on employees to attend work and the impact of attendance on performance. Human Reesource Management Journal, 20(3), p. 311-328. https://doi.org/10.1111/ j.1748-8583.2009.00118.x.

Baxter, S. - Sanderson, K. - Venn, A. J. - Blizzard, C. L. - Palmer, A. J. (2014): The relationship between return on investment and quality of study methodology in workplace health promotion programs. American Journal of Health Promotion, 28(6), p. 347-363. DOI: 10.4278/ajhp.130731LIT-395.

Boles, M. - Pelletier, B. - Lynch, W. (2004): The relationship between health risks and work productivity. Journal of Occupational and Environmental Medicine, 46(7), p. 737-745. DOI: 10.1097/01.jom.0ooo131830.45744.97.

Ввоокs, C. (2015): Nap Time? Sleeping at Work Boosts Productivity. https://www.businessnewsdaily.com/8165-sleeping-at-work.html (downloaded on 08.10.2018).

Burton, W. N. - Chen, C. Y. - Conti, D. J. - Schultz, A. B. - Edington, D. W. (2006): The association between health risk change and presenteeism change. Journal of Occupational and Environmental Medicine, 48(3), p. 252-263. DOI:10.1097/01.jom.0ooo201563.18108.af.

DABRóNAKI, Á. (2017): The most serious psychosocial risk at the workplace [A legkomolyabb munkahelyi pszichoszociális kockázat: a stressz]. https://jogaszvilag.hu/cegvilag/a-legkomolyabbmunkahelyi-pszichoszocialis-kockazat-a-stressz/ (downloaded on 08.10.2018).

DeVol, R. - Bedroussian, A. (2007). An Unhealthy America: The Economic Burden of Chronic Disease Charting a New Course to Save Lives and Increase Productivity and Economic Growth. Milken Institute. Santa Monica, https://www.milkeninstitute.org/publications/view/321 (downloaded on 08.10.2018).

Dongen, J. M. - Proper, K. I. - Van Wier, M. F. - Van Der Beek, A. J. - Bongers, P. M. - Van Mechelen, W. - VAN Tulder, M. W. (2011): Systematic review on the financial return of worksite health promotion programmes aimed at improving nutrition and/or increasing physical activity. Obesity Reviews , 12(12), p. 1031-1049. DOI: 10.1111/j.1467-789X.2011.00925.x. 
EU-OSHA (2018): Prevention of work-related diseases, https://osha.europa.eu/en/highlights/prevention-work-related-diseases-eu-osha-launches-new-website-section?pk campaign=OSHmail\%2003\%202018. (downloaded on 10.03.2018).

Eurobarometer (2010): Sport and physical acticity. ec.europa.eu/commfrontoffice/publicopinion/ archives/eb/eb74/eb74_publ_en.pdf (downloaded on 12.05.2015)

Eurobarometer (2014): Sport and physical acticity. http://ec.europa.eu/public_opinion/archives/ebs/ ebs12_en.pdf (downloaded on2015. május 12.)

Eurofound (2010): Work-related stress., https://www.eurofound.europa.eu/publications/report/2010/ work-related-stress (downloaded on 01.10.2018).

Eurofound (2012): Health and Wellbeing at Work: A Report Based on the Fifth European Working Conditions Survey, European Foundation for the Improvement of Living and Working Conditions http://www.eurofound.europa.eu/pubdocs/2013/o2/en/1/EF1302EN.pdf (downloaded on 13.01.2016).

European Agency for Safety and Health at Work (2010): European Survey of Enterprises on New and Emerging Risks. Managing safety and health at work. https:/osha.europa.eu/en/node/6745/ file_view (downloaded on 11,01.2015).

European Commission (2017): Safer and Healthier Work for All - Modernisation of the EU Occupational Safety and Health Legislation and Policy, Brussels, 10.1.2017 COM(2017) 12 final.

Eurostat (2018): Gross domestic product at market prices, https://ec.europa.eu/eurostat/tgm/table. do?tab=table\&init $=1 \&$ language $=$ en $\&$ pcode $=$ tecoooo $\&$ plugin $=1($ downloaded on 30.09 .2018$)$.

Garrow, V. (2016): Preseteeism. A review of current thinking. Institute for Employment Studies, UK: Brigthon.

Goetzel, R. Z. - Pei, X. - Tabrizi, M. - Henke, R. - Kowlessar, N. - Nelson, F.C. - Metz, R. (2012): Ten Modifiable Health Risk Factors Are Linked to More Than One-Fifth of EmployerEmployee Health Care Spending. Health Affairs, 31(11), p. 2474-2484. 10.1377/hlthaff.2011.0819.

Goetzel, R. Z. - Roemer, E. C. - Liss-Levinson, R. C. - Samoly, D. K. (2008): Workplace Health Promotion: Policy Recommendations that Encourage Employers to Support Health Improvement Programs for their Workers. http://prevent.org/data/files/initiatives/workplacehealtpromotion-policyrecommendations.pdf (downloaded on 01.11.2017).

Hayman, S. (2016): The Relationship Between Health Risk and Workplace Productivity in Saudi Arabia. Doctoral Dissertation, Walden University, https://scholarworks.waldenu.edu/dissertations/3034/ (downloaded on 08.10.2018).

Health Management (2018): A brief history of occupational health, https:/www.healthmanagement. co.uk/sites/default/files/paragraph/image/Health-Management_brief-history-occupationalhealth.pdf (downloaded on 04.11.2018).

Henke, R. M. - Goetzel, R. Z. - Mchugh, J. - IsaAC, F. (2011): Recent experience in health promotion at Johnson \& Johnson: lower health spending, strong return on investment. Health Affair, 30(3), 490-499. DOI: 10.1377/hlthaff.2010.0806.

Hungarian Work Stress Survey (2013): Results [Országos Munkahelyi Stressz Felmérés: Eredmények], http://www.munkahelyistresszinfo.hu/a-munkahelyi-stressz-merese/munkahelyistressz-felmeres-eredmenyek/ (downloaded on 08.10.2018).

International Organization for Standardization (2018): ISO 31000 - Risk management, https://www. iso.org/iso-310oo-risk-management.html (downloaded on 11.03.2018).

Kirkham, H. - Bobby, L. C. - Bolas, C. A. - Lewis, G. H. - Jackson, A. S. - Fisher, D. - Duncan, I. (2015): Which Modifiable Health Risks Are Associated with Changes in Productivity Costs? Population Health Management 18(1), https://doi.org/10.1089/pop.2014.0033.

KPMG Econtech (2011): Economic Modelling of the Cost of Presenteeism in Australia: 2011 Update, Report for MediBank Private, August 2011. 
KSH (2018a): Value of gross domestic product in HUF, EUR, USD, and in purchasing power parity (1995-), http://www.ksh.hu/docs/eng/xstadat/xstadat_annual/i_qpto15.html (downladed on 30.09.2018).

KSH (2018b): Working time balance 2016 [Munkaidőmérleg 2016], Statisztikai Tükör, 2 July 2018, http://www.ksh.hu/docs/hun/xftp/stattukor/munkaidomerleg16.pdf (downloaded on 07.11.2018).

LECHNER, M. (2009): Long-run labour market and health effects of individual sports activities. Journal of Health Economics, 28 (4), p. 839-854.

Lenneman, J. - Schwartz, S. - Giuseffi, D. L. - Wang, C. (2011): Productivity and health: an application of three perspectives to measuring productivity. Journal of Occupational and Environmental Medicine, 53(1), p. 55-61, DOI: 10.1097/JOM.obo13e3182029110.

Merrill, R. M. - Aldana, S. G. - Pope, J. E. - Anderson, D. R. - Coberley, C. R. - Grossmeier, J. J. - Whitmer, R. W. (2013): Self-rated job performance and absenteeism according to employee engagement, health behaviors, and physical health. Journal of Occupational and Environmental Medicine, 55(1), p. 10-18. DOI: 10.1097/JOM.obo13e31827b73af.

MGYOSZ (2010): For healthy workers and safe workplaces [Az egészséges munkavállalókért és a biztonságos munkahelyekért], www.euromenedzser.hu/hu/kiadvanyaink (downloaded on 01.11.2013).

MiLLs, P. R. (2005): The development of a new corporate specific health risk measurement instrument, and its use in investigating the relationship between health and well-being and employee productivity. Environmental Health, 4(1), 1. DOI: 10.1186/1476-069X-4-1.

O'Donnell, M. P. (2000): Health and productivity management: the concept, impact and opportunity. Commentary to Goetzel and Ozminkowski. American Journal of Health Promotion, 20oo, 14 , p. 215-217.

OECD (2017): Obesity Update. https://www.oecd.org/els/health-systems/Obesity-Update-2017.pdf (downloaded on 08.10.2018).

Oliveira, K. - MéXas, M. - Meiriño, M. - Drumond, G. (2018): Critical success factors associated with the implementation of enterprise risk management. Journal Of Risk Research, p. 1-16, DOI: 10.1080/13669877.2018.1437061.

Pelletier, B. - Boles, M. - Lynch, W. (2004): Change in health risks and work productivity over time. Journal of Occupational and Environmental Medicine, 46(7), p. 746-754.

Pénzcentrum (2018): A serious epidemic, more dangerous than smoking, strikes the Hungarian population [Súlyos népbetegség ütötte fel a fejét: veszélyesebb, mint a dohányzás], https://www. penzcentrum.hu/biztositas/sulyos-nepbetegseg-utotte-fel-a-fejet-veszelyesebb-mint-a-dohanyzas.1070458.html (downloaded on 08.10.2018).

PolGár, B. (2018): Are we a country of the obese? [A kövérek országa vagyunk?], https://www.veol. hu/eletstilus/helyi-eletstilus/hazankban-felmeres-szerint-harom-felnottbol-ketto-tulsulyosvagy-elhizott-2221673/ (downloaded on 08.10.2018)

Rand Europe (2016): Why sleep matters - the economic costs of insufficient sleep. A cross-country comparative analysis, https://www.rand.org/pubs/research_reports/RR1791.html (downloaded on 08.10 .2018$)$.

Randstad Workmonitor (2014): Healthy employees perform better. https://www.randstad.com/.../ randstad-workmonitor (downloaded on 11.01.2015).

Serxiner, S. - Gold, D. B. - Bultman, K. K. (2001): The impact of behavioral health risks on worker absenteeism. Journal of Occupational and Environmental Medicine, 43(4), p. 347-354.

Sleep Council, The (2013): The Great British Bedtime Report. https://www.sleepcouncil.org.uk/wpcontent/.../The-Great-British-Bedtime-Report.pdf (downloaded on 08.10.2018). 
Szabó, A. (2018): A Magyar GDP hatszorosába kerül évente Európában a munkahelyi stressz. http:// www.munkahelyistresszinfo.hu/stressz-a-munkahelyen/a-stressz-hatasai/a-magyar-gdphatszorosaba-kerul-evente-europaban-a-munkahelyi-stressz.php (downloaded on 08.10.2018).

Szinapszis (2013): Már a munkahelyen is számít az egészség. http://www.webbeteg.hu/cikkek/ egeszseges/14720/mar-a-munkahelyen-is-szamit-az-egeszseg ( downloaded on 10.08.2013).

Tasmania (2012): Your Simple Guide to Workplace Health and Wellbeing. http://worksafe.tas.gov. au/__data/assets/pdf_file/ooo3/252390/Your_Simple_Guide_to_Workplace_Health_and_ Wellbeing.pdf (downloaded on 11.01.2015).

VAughan-Jones, H. - BARHAM, L. (2009): Healthy Work Challenges and Opportunities to 203o. London: Press Office Bupa.

Virgin Pulse (2017): Clocking in and checking out, https:/connect.virginpulse.com/files/presenteeism-in-the-workplace.pdf (downloaded on 07.11.2018).

Vöő, Gy. (2018): Csúcsot döntött az igazolatlan munkahelyi távollét, https://www.vg.hu/gazdasag/ gazdasagi-hirek/csucsot-dontott-az-igazolatlan-munkahelyi-tavollet-2-985216/ (downloaded on 01.11.2018).

WHAA (2016): ROI White Paper. Workplace Health Association of Australia.

WHO (2010): Healthy Workplace Framework and Model, www.who.int/occupational_health/ healthy_workplace_framework.pdf (downloaded on 01.07.2013).

Willis Towers Watson (2016): Employee Health and Business Success. https://www.willistowerswatson.com/en/insights/2016/03/stayingatwork-report-employee-health-and-business-success (downloaded on 01.11.2018).

Witters, D. - Agrawal, S. (2015): Well-Being Enhances Benefits of Employee Engagement. Business Journal, October 27, http://news.gallup.com/businessjournal/186386/enhances-benefitsemployee-engagement.aspx (downloaded on 28.02.2018).

Xerox (2016): Working Well: A Global Survey of Workforce Wellbeing Strategies 2016 - Survey report, 7th ed., http://www.globalhealthyworkplace.org/casestudies/2016_Global_Wellbeing Survey_Executive-Summary.pdf (downloaded on 10.02.2018). 